\title{
Use of Coimmobilized Biological Systems to Degrade Toxic Organic Compounds
}

\author{
Jian-Er Lin* and Henry Y. Wang ${ }^{\dagger}$ \\ Department of Chemical Engineering, The University of Michigan, Ann Arbor, \\ Michigan 48109 \\ Robert F. Hickey \\ Michigan Biotechnology Institute, Lansing, Michigan 48909
}

Received June 18, 1990/Accepted January 7, 1991

\begin{abstract}
The concept of coimmobilizing cell mass (and/or enzyme) and adsorbent in a hydrogel matrix for biodegradation of toxic organic chemicals was introduced. Under defined experimental conditions, the coimmobilized system using activated carbon and Phanerochaete chrysosporium was compared with nonimmobilized systems for the degradation of pentachlorophenol (PCP). It was demonstrated that the coimmobilized system degraded PCP more effectively than the nonimmobilized system. A solid substrate included in the coimmobilized system could support the biodegradation. Isolation of the degrading agents from a model interrupting microorganism by the coimmobilized capsule membrane reduced the interference on the biodegradation. In simulated contaminated soil extract and sand, the coimmobilized system also exhibited higher degradative ability and stability than the nonimmobilized systems.

Key words: coimmobilization - Phanerochaete chrysosporium - pentachlorophenol • biodegradation - adsorption
\end{abstract}

\section{INTRODUCTION}

Inoculation of microorganisms with identified metabolic capacities is considered one of the promising approaches to enhancing biodegradation of toxic organic compounds in the environment. Many laboratory-identified microorganisms, both in pure culture and mixed culture, have been shown to be effective for degrading recalcitrant organic compounds. ${ }^{6}$ Effective utilization of laboratoryidentified organisms at contaminated sites may depend on solutions to two problems. First, mobility of toxic chemicals may result in their unavailability for biodegradation. When flow of the mobile phase is faster than biodegradation, toxic chemicals dissolved in the mobile phase may migrate to other areas ${ }^{2}$ and thus are unavailable for the inoculated microorganisms. Second, environmental conditions at waste sites are often unfavorable for degrading organisms. ${ }^{11,17}$ Hydrogeological properties, nutrient conditions, toxic chemical concentration, temperature, $\mathrm{pH}$, etc., at contaminated sites are usually site specific and much different from those required by the degrading organisms. ${ }^{4,11}$ In addition, interrupting microflora and some inhibitory substances may also interfere with the performance of the target microorganisms. ${ }^{4,11}$

* Current address: Michigan Biotechnology Institute, 3900 Collins Road, P.O. Box 27609, Lansing, MI 48909.

${ }^{\dagger}$ To whom all correspondence should be addressed.
This study proposed coimmobilizing cell mass (and/or enzymes) and adsorbent particles in a hydrogel matrix for biodegradation of toxic chemicals. The coimmobilized system is composed of three components, a biodegrading agent (cells and/or enzymes), an adsorbent, and an immobilization matrix. The major function of the adsorbent is to concentrate toxic contaminants in the coimmobilized system. The immobilization matrix combines the degrading agent and adsorbent within a favorable microenvironment. Solid cosubstrates can also be immobilized in the matrix. The coimmobilized system can be manufactured by either entrapment or encapsulation technology. It was expected that the coimmobilized system could enhance migration of toxic compounds from the environment to the adsorbent and provide a controlled microenvironment for subsequent biodegradation.

Similar to the co-immobilized system, a conventional bioadsorbent (such as bioactivated carbon) process also operates with an adsorption-biodegradation mechanism. ${ }^{3,14,15,18}$ In addition, matrix-immobilized cells have also been used for biodegradation of toxic chemicals. ${ }^{10}$ Provided the coimmobilization process does not reduce the adsorptive capacity of the coimmobilized adsorbent, the coimmobilization approach, similar to the bioadsorbent, can concentrate toxic chemicals from the contaminated mobile phase to the adsorbent, reduce inhibition on degrading microorganisms and enzymes, and minimize volatile pollution. All these advantages related to adsorption cannot be realized by the conventional matrix-immobilized cells. The bioadsorbent process usually can only use fine adsorbent particles (such as powdered activated carbon) in a batch operation and requires adsorbents with large particle size if used in a flow system. ${ }^{2}$ Also, immobilization through adsorption of microbial cells in the bioadsorbent process is very much dependent on the types of adsorbents and cells and the hydrodynamic conditions. ${ }^{14}$ The coimmobilization approach can avoid these limitations, thus providing a potential means to coimmobilize various adsorbents and cells in a controllable condition. Furthermore, the coimmobilization matrix can retain the solid cosubstrate, reduce or avoid interference from interrupting organisms, and isolate the biodegrading 
agents from the heterogeneous environment in the contaminated sites, thereby creating favorable microenvironmental conditions for biodegradation.

In this study, coimmobilized hydrogel capsules using activated carbon and the white rot fungus Phanerochaete chrysosporium to degrade pentachlorophenol (PCP) were applied as a model system to test the proposed concept. Various characteristics of the coimmobilized system were examined under defined experimental conditions. The potential utility of this concept was also investigated using simulated contaminated soil extract and sand.

\section{MATERIALS AND METHODS}

\section{Model Experimental System}

Coimmobilized capsules were used to degrade PCP in this study. Three major components of the coimmobilized capsules were cell mass and extracellular enzymes from pregrown cultures of the white rot fungus Phanerochaete chrysosporium (degrading agents), powdered activated carbon (adsorbent), and $\mathrm{Ca}$-alginate (matrix of the capsule membrane). Figure 1 shows a typical photograph of the coimmobilized carbon-fungus capsules. In these experiments, glucose and cellulose were used as soluble and insoluble cosubstrates to support the biodegradation. Aspergillus 3181 was applied as a model interrupting organism in the experiment for demonstrating the effect of isolating the target degrading organisms from the interrupting microbes.

\section{Microorganism and Culture Conditions}

The fungus $P$. chrysosporium (BKM-F-1767) was obtained from Dr. T. K. Kirk (USDA Forest Products Lab., Madison, WI). The fungus was maintained on $2 \%$ malt agar slants. The culture was grown in DMS $(2,2-$ dimethyl succinate) medium ${ }^{12}$ as detailed by Lin et al. ${ }^{8}$

\section{Preparation of Coimmobilized Capsules, Encapsulated Activated Carbon, and Immobilized Capsules}

After 7 days of incubation, the mycelial mat and extracellular enzyme fluid were harvested and separated from $P$. chrysosporium culture by centrifugation. The mycelia were homogenized using a glass homogenizer. The crude extracellular enzyme fluid was concentrated 10 - to 20 -fold by a membrane filter $(10,000 \mathrm{MW}$ cutoff, Amicon, W. R. Grace \& Co., Danvers, MA). The cell mass was quantified using wet cell volume which was then converted to dry cell weight. ${ }^{8}$ The Bio-Rad method (Bio-Rad Laboratories, Richmond, CA) was used to determine the amount of total protein in the enzyme concentrate. ${ }^{8}$ The specific ligninase activity of the extracellular fluid was $0.095 \mathrm{~A}_{310} / \mathrm{min}-\mu \mathrm{g}$ protein. ${ }^{8}$ To prepare coimmobilized capsules, homogenized cell

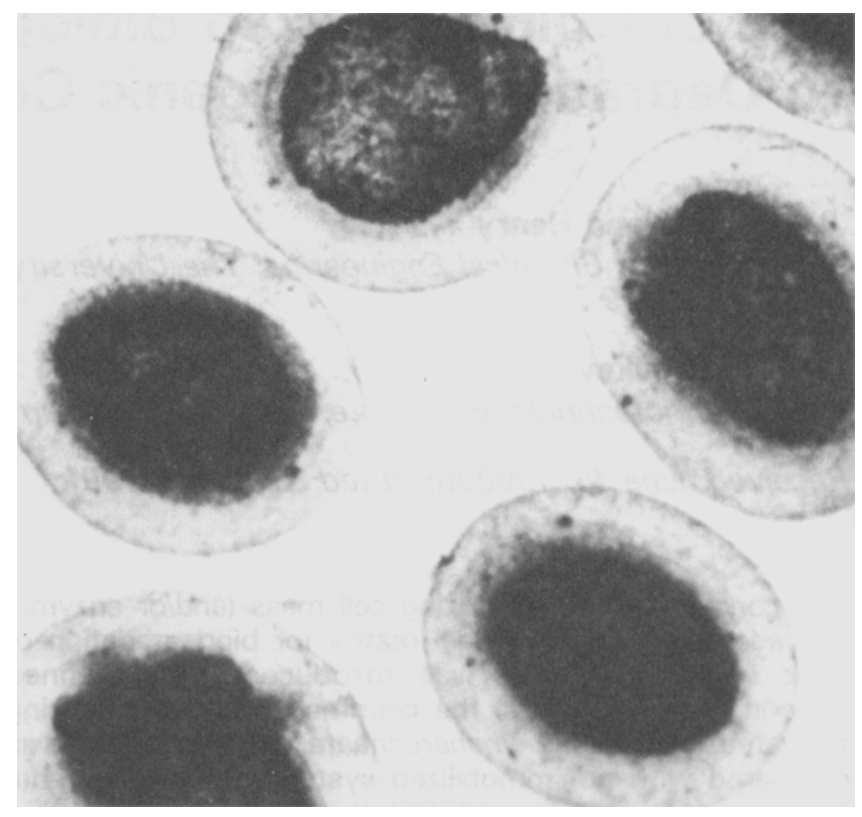

Figure 1. Photograph of coimmobilized carbon-fungus capsules.

mass $(0.5 \mathrm{~mL})$, crude enzyme concentrate $(1.0 \mathrm{~mL})$, and a desired amount of powdered activated carbon (Darco, G-60, 100 mesh) were mixed with $0.3 \mathrm{M} \mathrm{CaCl}_{2}$ solution to a total of $2.5 \mathrm{~mL}$ (for one flask of degradation mixture). This mixture was then dropped through an air nozzle into a stirred alginate solution ( $0.5 \%$ ). Mixing was continued for $2 \mathrm{~min}$. The slurry of the formed capsules and alginate solution was then diluted about fivefold with distilled water to quench the reaction between $\mathrm{Ca}^{2+}$ and alginate. The capsules were washed with $10 \mathrm{~m} M$ DMS buffer. For the experiments evaluating the utility of including solid cosubstrates, cellulose $(0.08 \mathrm{~g})$ was immobilized in the capsules with the cell mass, enzymes, and carbon. Encapsulated activated carbon was prepared by the same procedure except the cell mass and enzymes were omitted. Immobilized capsules (only cell mass and enzymes immobilized) were made with the same procedure but without inclusion of activated carbon. The diameter of coimmobilized capsules, encapsulated carbon, and immobilized capsules used in this experiment was $3.0 \pm 0.2 \mathrm{~mm}$.

\section{Assays for PCP in Aqueous Solution and PCP Mineralization $\left({ }^{14} \mathrm{CO}_{2}\right.$ release)}

PCP in solution was assayed by high-performance liquid chromatography (HPLC) using a modification of the technique of Mikesell et al. ${ }^{8,9}$

Evolved ${ }^{14} \mathrm{CO}_{2}$ was assayed by trapping in $10 \mathrm{~mL}$ of an ethanolamine-containing scintillation fluid. ${ }^{5}$ Degradation mixture was contained in flasks fitted with ports that permitted periodic flushing for ${ }^{14} \mathrm{CO}_{2}$ release. Air was used for flushing at a flow rate of $100-200 \mathrm{~mL} / \mathrm{min}$ for a total of $20 \mathrm{~min}$. The radioactivity trapped in the 
scintillation fluid was then determined using a liquid scintillation spectrometer (Beckman LS 3801). Data of ${ }^{14} \mathrm{CO}_{2}$ release were corrected for background radioactivity and for counting efficiency. The latter was determined with an internal standard of ${ }^{14} \mathrm{C}$-toluene.

\section{PCP Adsorption}

PCP adsorption was carried out in 500-mL flasks containing $150 \mathrm{~mL}$ of $25 \mathrm{mM}$ DMS buffer solution with $7 \mathrm{~g} / \mathrm{L}$ glucose $(\mathrm{pH} 4.5)$. Powdered activated carbon $(20 \mathrm{mg})$, in either a free form or an encapsulated form, was added to each flask. An $827 \mu \mathrm{mol} / \mathrm{L}$ PCP stock solution was added into the flask to attain desired initial concentrations (ranging from 30 to $138 \mu \mathrm{mol} / \mathrm{L}$ ). The stock solution was prepared by dissolving PCP (Aldrich Co., Milwaukee, WI) in double-distilled water and adjusting the $\mathrm{pH}$ to 11.0 with $1 \mathrm{~N} \mathrm{NaOH}$ to increase PCP solubility. All the flasks were maintained at $38^{\circ} \mathrm{C}$ on a 130-rpm shaker. Equilibrium adsorption of PCP was determined by measuring the decrease of the aqueous PCP concentration after $72 \mathrm{~h}$ adsorption.

\section{Mineralization of PCP in DMS Buffer}

Coimmobilized capsules prepared according to the above procedure were added to each flask $(250 \mathrm{~mL})$. For all the control experiments mentioned in the text, the same amounts of nonimmobilized cell mass, enzymes, and carbon were used. Each flask contained a mixture of ${ }^{14} \mathrm{C}$-labeled PCP (with purity of $99.4 \%$ PCP and specific activity of $12.3 \mathrm{mCi} / \mathrm{mmol}$, Sigma Chemical Co., St. Louis, MO) and unlabeled PCP $(1.5 \mathrm{~mL})$ and $18.5 \mathrm{~mL}$ of $25 \mathrm{~m} M$ DMS buffer ( $\mathrm{pH} 4.5$, with $7 \mathrm{~g} / \mathrm{L}$ glucose; otherwise as indicated in the text). The initial PCP concentration in the degradation solution was $59 \mu \mathrm{mol} / \mathrm{L}$, and the total radioactivity contained was approximately $0.03 \mu \mathrm{Ci}$. Flasks were maintained at $38^{\circ} \mathrm{C}$ and air atmosphere (except as mentioned in the text) on an 80-rpm shaker. For the experiments indicating reduction of interference from indigenous organisms, a model interrupting organism, Aspergillus 3181 (homogenized mycelia, $2 \mathrm{~mL}$ wet vol), was added to the samples. PCP mineralization was measured at the indicated intervals.

\section{Tests in Simulated Contaminated Soil Extract and Sand}

Distilled water was used to extract soil (nonsterile sandy loam, Ingham County, MI) in a shaken flask for $24 \mathrm{~h}$ $(5: 1 \mathrm{v} / \mathrm{w})$. The supernatant of the soil slurry was then removed and adjusted with $1 N \mathrm{HCl}$ to $\mathrm{pH} 4.0$. Coimmobilized capsules or nonimmobilized cell mass and enzymes plus granular activated carbon were placed in flasks containing a mixture of ${ }^{14} \mathrm{C}-\mathrm{PCP}$ and unlabeled PCP $(827 \mu \mathrm{mol} / \mathrm{L}, 1.5 \mathrm{~mL})$, soil extract $(18.5 \mathrm{~mL})$, and glucose $(0.14 \mathrm{~g})$.
For experiments using sand, nonsterile silica sand (20 g, average diameter $0.45 \mathrm{~mm}$, Tamms Industries Co., Itasca, IL) was added to a flask with $4 \mathrm{~mL}$ of distilled water ( $\mathrm{pH} 4.0$ ). Coimmobilized capsules, nonimmobilized cell mass and enzymes, or cell mass and enzymes plus powdered activated carbon and the mixed PCP solution $(827 \mu \mathrm{mol} / \mathrm{L}, 1.5 \mathrm{~mL})$ were then added. At the beginning, cellulose $(10 \mathrm{mg})$ was coimmobilized in the capsules or added into the two nonimmobilized systems. At $275 \mathrm{~h}$, glucose $(30 \mathrm{mg})$ was added into each flask.

In addition to the determination of ${ }^{14} \mathrm{CO}_{2}$ release, the radioactivity remaining in the aqueous phase of the above systems was also measured using a scintillation spectrometer. Other experimental conditions were the same as those used for PCP mineralization in DMS buffer.

\section{RESULTS AND DISCUSSION}

\section{Profiles of PCP Removal and Degradation}

Profiles of PCP removal and degradation by the coimmobilized capsules are shown in Figure 2. Ninety-five percent of the PCP was removed from the buffer solution within $25 \mathrm{~h}$ under different experimental conditions. PCP mineralization occurred at a much lower rate than the removal and continued for a long period. Different mineralization rates were observed when using different amounts of activated carbon, cell mass, and enzymes. For the period of $300 \mathrm{~h}$, about $10 \%$ of added PCP was mineralized when using the coimmobilized capsules with $5 \mathrm{mg}$ of carbon, while approximately $3.5 \%$ of PCP mineralized when using the capsules with $20 \mathrm{mg}$ of carbon. These results initially indicate that the coimmobilized system manufactured by the encapsulation technique can realize the expected removal and biodegradation of toxic chemicals.

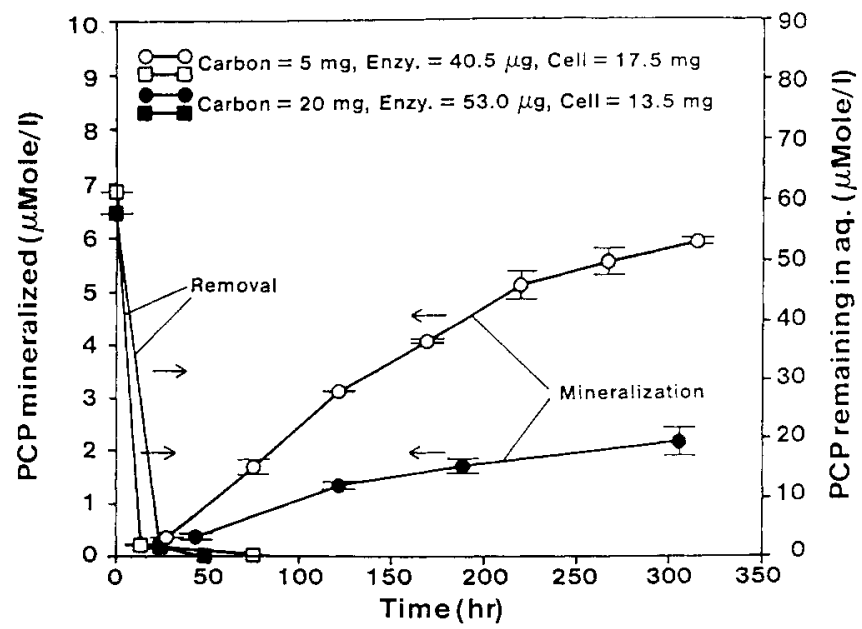

Figure 2. Profiles of PCP removal and degradation by coimmobilized capsules with different amounts of activated carbon, extracellular enzymes, and cell mass. Data are the average of duplicate samples. 
In the process of PCP degradation, extracellular enzymes from $P$. chrysosporium oxidize PCP into some intermediates, and the cell mass mediates the mineralization step. ${ }^{8}$ When the coimmobilized capsules were used in the buffer, adsorption of PCP by the coimmobilized activated carbon, enzymatic conversion of PCP, and direct mineralization of PCP by cell mass might occur in parallel. The intermediates from the enzymatic conversion could be further mineralized by the cell mass. Based on the determination of various kinetic parameters, ${ }^{7,8}$ the rate constant of PCP adsorption by the coimmobilized activated carbon was about 5 times as high as that of PCP conversion by the enzymes and was approximately 500 and 50 times that of PCP and the intermediate mineralization by the cell mass, respectively. After a short period of time (such as $25 \mathrm{~h}$ in Fig. 2), the majority of the added PCP and a small fraction of intermediates were adsorbed to the activated carbon. Occurrence of continuous mineralization after this period suggests the biodegradation of the adsorbed PCP and intermediates. During the process occurring in the coimmobilized system, the adsorbent operates as a reservoir of toxic compounds. The percentage of mineralization by the coimmobilized system is determined by the amount of PCP added, content of activated carbon, and activity of the enzymes and cell mass.

\section{Comparison of PCP Adsorption by Encapsulated and Free Activated Carbon}

To examine the effects of the coimmobilization process on the adsorptive capacity of the carbon, experiments were conducted using encapsulated activated carbon and nonimmobilized activated carbon in DMS buffer. As shown in Figure 3, the isotherms of PCP adsorption by encapsulated activated carbon and free activated carbon are indistinguishable, indicating the coimmobi-

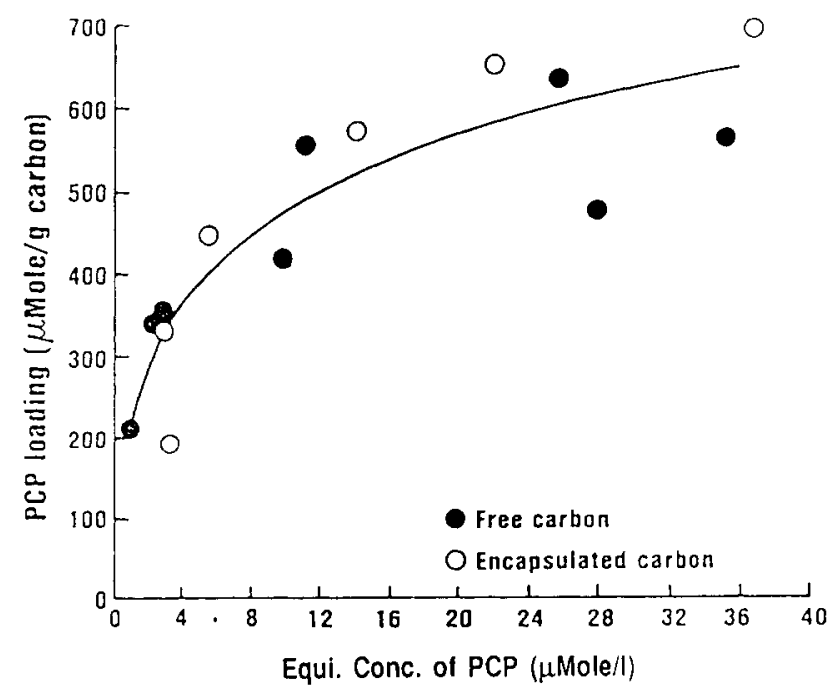

Figure 3. Comparison of adsorption isotherms of PCP by encapsulated activated carbon and free activated carbon. lization process does not adversely affect the adsorptive capacity of the adsorbent.

The adsorptive capacity of the coimmobilized adsorbent is mainly determined by two factors: molecular characteristics of toxic compounds, such as molecular weight and structure, and properties of immobilization matrices, such as pore size. The high end of the range of molecular weights of common nonaggregated toxic compounds is on the order of magnitude of hundreds (e.g., hexachlorobiphenyl, 361; PCP, 266). Most materials used as immobilization matrices possess a pore size which allows movement of molecules with a molecular weight on the order of magnitude of 10,000 . For instance, substances with a molecular weight of 20,000 can easily diffuse into the alginate matrix. ${ }^{16}$ Therefore, adsorptive capacity of the coimmobilized adsorbent should not be adversely affected by the coimmobilization process given a rational selection of the immobilization matrices and the preparation procedures.

\section{PCP Mineralization by Coimmobilized Capsules Compared with Reference Systems}

Developing close contact between the toxic chemicals, cell mass, and enzymes is a major characteristic and suggested an advantage of the coimmobilized system. In order to demonstrate this concept, coimmobilized capsules were compared with a reference system, nonimmobilized cell mass, enzymes, and carbon (in DMS buffer). Another system, immobilized capsules with carbon in solution, in which carbon and cell mass were intentionally separated by the capsule membrane, was also tested.

In the nonimmobilized system, the majority of the fungal cell mass could not be adsorbed by the activated carbon (only a small amount of the carbon attached to the cell mass). Most of the cell mass was, therefore, spatially separated from the adsorbent (therefore the adsorbed PCP and intermediates), even though the carbon could adsorb the extracellular enzymes. ${ }^{7}$ As shown in Figure 4, the amount of PCP mineralized by coimmobilized capsules was about $110 \%$ higher compared to the nonimmobilized system for a 500 -h observation period (approximately $4.6 \%$ vs. $2.2 \%$ ). Immobilized capsules with carbon in solution had the lowest PCP mineralization $(1.3 \%)$. The mineralization capacities of these three experimental systems were in accordance with the degree to which cell mass contacted the activated carbon. A difference in the mineralization rate between using coimmobilized capsules and other two systems mainly occurred during the first $200 \mathrm{~h}$. Beyond $200 \mathrm{~h}$, the rate of PCP mineralization using the coimmobilized system decreased, probably reflecting the decrease in activity of the coimmobilized enzymes and cell mass (a similar decrease was also observed for the degradation of $\mathrm{PCP}^{8}$ and other toxic compounds ${ }^{1}$ using free enzymes and cell mass of $P$. chrysosporium). 


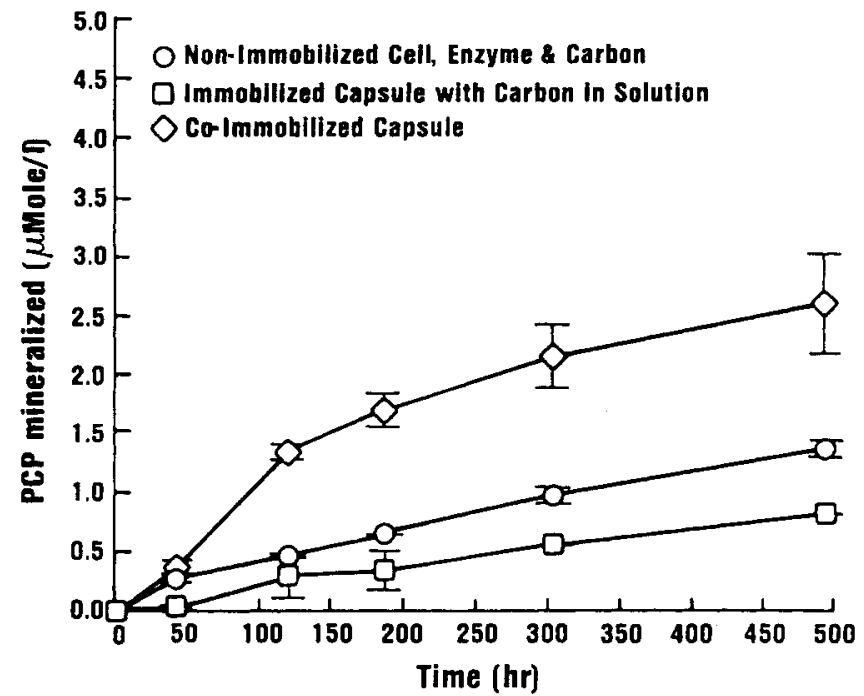

Figure 4. Comparison in PCP mineralization using coimmobilized capsules, nonimmobilized system, and immobilized capsules with carbon in solution. Data are the average of duplicate samples. Cell mass, $15 \mathrm{mg}$; extracellular enzymes, $60 \mu \mathrm{g}$ protein; activated carbon, $20 \mathrm{mg}$.

PCP concentration in the bulk phase for the three experimental systems was similar and too low to be detected beyond $50 \mathrm{~h}$. Because there was no capsule membrane, the nonimmobilized system is more favorable for utilization of the cosubstrate (glucose) and $\mathrm{O}_{2}$ than the coimmobilized capsules. The diffusion resistance in the immobilization matrix for both the coimmobilized capsules and the immobilized capsules was similar. Under these conditions, coimmobilized capsules could degrade PCP more effectively than the nonimmobilized system and immobilized capsules with carbon in solution. This suggests that the close contact between cell mass and adsorbent particles created by coimmobilization is likely responsible for the higher PCP degradation capacity. The close contact may reduce the length of diffusion path of toxic compounds and intermediates to the degrading agents and maintain higher concentrations of these reactants in the coimmobilization matrix, thus increasing degradation efficiency. ${ }^{13}$ When cell mass (and/or enzymes) and adsorbent are coimmobilized in capsules, the proximity between them can be artificially adjusted through the choice of the types and physical properties (such as pore diameter and particle size) of the adsorbent and the amounts of adsorbent and cell mass.

\section{Effect of Retaining Solid Cosubstrate in Coimmobilized Capsules}

Figure 5 shows the effect of incorporating a solid cosubstrate (cellulose) in the coimmobilization matrix. With no cosubstrate (glucose or coimmobilized cellulose), PCP mineralized by the capsules was essentially the same as the background level. The same phenomenon was also observed by adding cellulose in the buffer

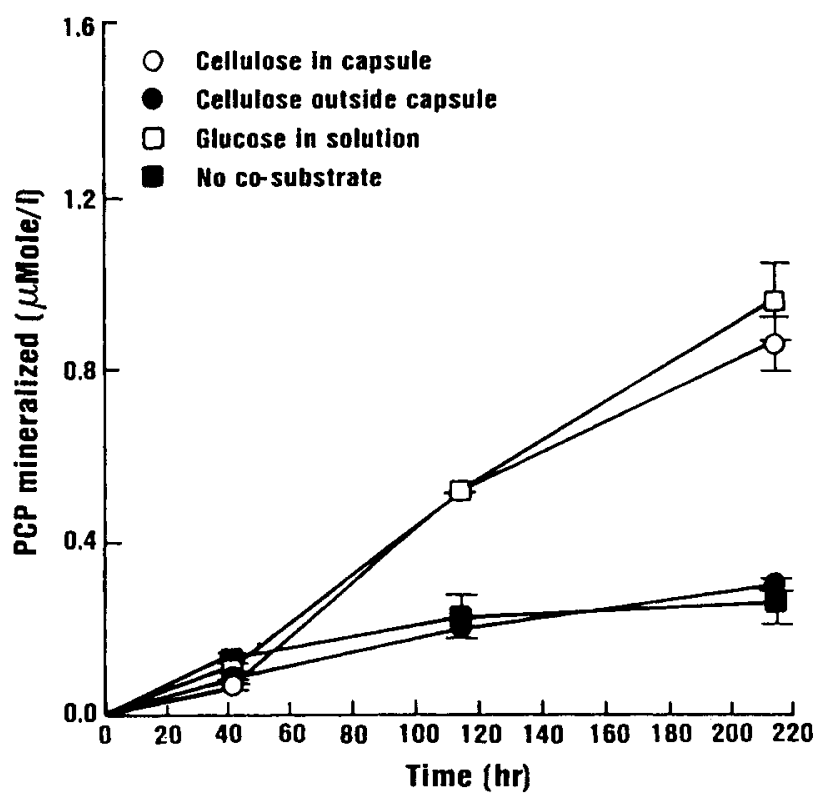

Figure 5. Effect of coimmobilized cellulose on PCP mineralization. Data are the average of duplicate samples. Cell mass, $19 \mathrm{mg}$; extracellular enzymes, $42 \mu \mathrm{g}$ protein; activated carbon, $20 \mathrm{mg}$.

solution (the cellulose was separated by the capsule membrane from the cell mass). When cellulose was coimmobilized with the cell mass and enzymes inside the capsules, the amount of PCP mineralization increased significantly, reaching the same degree as when glucose was used as a cosubstrate (approximately $1.7 \%$ for a $200-h$ period).

Degradation of toxic chemicals by $P$. chrysosporium is a cometabolism process in which a cosubstrate is required to carry out the biotransformation. ${ }^{1}$ The present results indicate that coimmobilization of soild nutrients is a feasible way of supplying substrates for a cometabolism process.

\section{Effect of Isolating Degrading Agents from Interrupting Microflora by the Capsule Membrane}

To determine if there was a potential benefit of isolating target organisms and enzymes using the capsule membrane, a model interrupting organism, Aspergillus 3181, was added into the degradation mixture using coimmobilized capsules or nonimmobilized cell mass, enzymes, and carbon. Samples without addition of Aspergillus were used as comparisons to determine the remaining activity of the degrading cells and enzymes. To avoid or reduce interference due to the competition for oxygen for both $P$. chrysosporium and Aspergillus, $\mathrm{O}_{2}$-rich air (approximately $90 \% \mathrm{O}_{2}$ ) was used to flush the samples when trapping ${ }^{14} \mathrm{CO}_{2}$. Figure 6 shows the normalized cumulative PCP mineralization by both coimmobilized capsules and the nonimmobilized system with Aspergillus compared with the related sample without Aspergillus (in DMS buffer). The normalized cumulative PCP mineralization was calculated by dividing the cumula- 


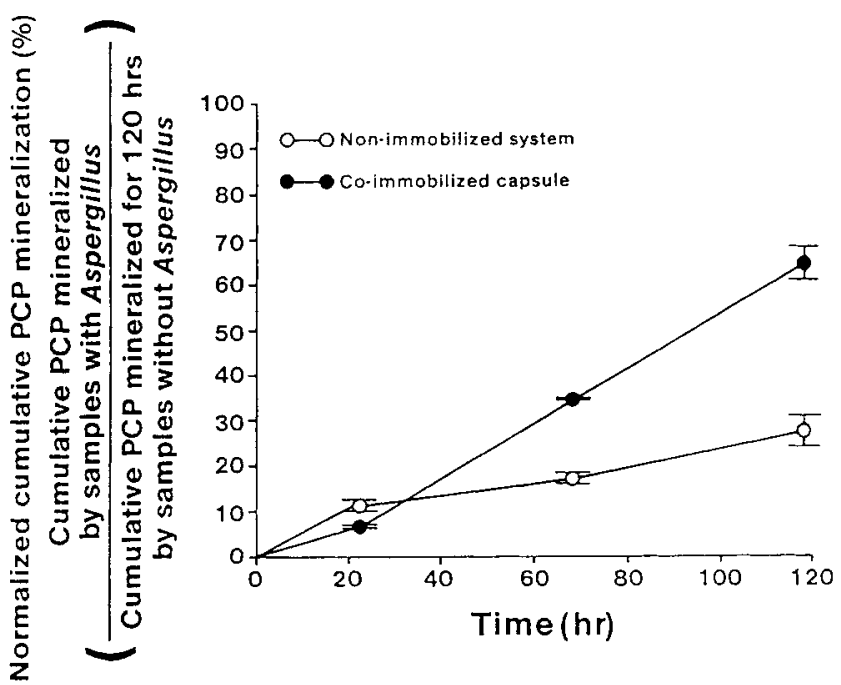

Figure 6. PCP mineralization by coimmobilized capsules and nonimmobilized system with Aspergillus 3181 in buffer. Data are the average of duplicate samples. Cell mass, $23 \mathrm{mg}$; extracellular enzymes, $74 \mu \mathrm{g}$ protein; activated carbon, $5 \mathrm{mg}$; at $90 \% \mathrm{O}_{2}$ atmosphere; inoculum of Aspergillus, $2 \mathrm{~mL}$ wet volume.

tive PCP mineralization of the sample with Aspergillus by that without Aspergillus (the latter was for $120 \mathrm{~h}$ ). At $120 \mathrm{~h}$, the normalized PCP mineralization by coimmobilized capsules was $68 \%$. At the same time, only approximately $17 \%$ of the normalized PCP mineralization was observed for the nonimmobilized system.

Interrupting microflora in contaminated sites has been suspected to decrease the efficiency of laboratoryidentified microorganisms added to contaminated sites. $^{4,11}$ There are two major potential reasons for the negative influence of interrupting microflora. First, competition for the same substrate leads to inactivation of the added microorganisms, especially when the interrupting microf lora has a faster growth rate. Second, the metabolic microenvironment of indigenous microflora may inhibit the function of added microorganisms if both are in close proximity. The proposed approach of coimmobilization can immobilize cosubstrates inside the matrix and isolate the target microorganism from the interrupting microbes, thus reducing competition and limiting contact between the added and the interrupting populations.

\section{Tests of Coimmobilized Capsules in Simulated Contaminated Soil Extract and Sand}

In order to examine the utility of the coimmobilized system to enhance biodegradation under environmental conditions, coimmobilized capsules were compared with several reference systems in simulated contaminated soil extract and sand (Table I). Granular activated carbon plus both cell mass and enzymes (Bio-GAC) may be applied to a continuous operation system to treat contaminated water (such as the soil-wash-type process). Based on this, the Bio-GAC process was used as a ref- erence system for coimmobilized capsules in the soil extract. Selection of amounts of both the coimmobilized powdered activated carbon (PAC) and the GAC was based on a similar retention time of $\mathrm{PCP}$ in the aqueous phase of soil extract when they were used. A preliminary experiment also demonstrated that PCP equilibrium loadings on both PAC and GAC were similar.

As shown in Table I, coimmobilized capsules had a higher degradation capacity and a longer effective degradation period compared with the reference systems. In soil extract and sand samples with the coimmobilized capsules or activated carbon, ${ }^{14} \mathrm{C}$-radioactivity in the aqueous phase (a measurement of PCP and degradation intermediates) disappeared within $48 \mathrm{~h}$, while the sand sample without activated carbon still maintained a high level of radioactivity even at 31 days (data not shown).

The coimmobilized adsorbent could rapidly remove the toxic compound from the soil extract. The higher amount of PCP mineralized by the coimmobilized capsules indicated that significant biodegradation of the adsorbed PCP occurred under the experimental conditions. The system using GAC, cell mass, and enzymes also removed PCP from the soil extract rapidly, but the biodegradation by this system was less efficient. Because of the separation of GAC from the cell mass and the resistance of mass transfer inside the GAC, PCP and degradation intermediate adsorbed in GAC were not easily accessible to the cell mass. This may be one of the reasons why the Bio-GAC process was less efficient than the coimmobilized system.

The intentionally contaminated sand had a lower water content $\left(32.5 \% \quad \mathrm{H}_{2} \mathrm{O} \mathrm{v} / \mathrm{w}\right)$ compared with other experimental systems. In this case, the cell mass in the reference system with PAC had better contact with the activated carbon than in the aqueous-phase-only experi-

Table I. PCP mineralization by coimmobilized capsules compared with reference systems in simulated contaminated soil extract and sand.

\begin{tabular}{lcc}
\hline \multicolumn{1}{c}{ Tested system } & $\begin{array}{c}\text { Effective } \\
\text { degradation time } \\
\text { (days) }\end{array}$ & $\begin{array}{c}\text { PCP }^{\text {mineralized }} \\
\text { (\%) }\end{array}$ \\
\hline In soil extract & \\
$\quad$ Capsules & & $13.03 \pm 0.83$ \\
$\quad$ GAC + cell + enzyme & 32 & $2.09 \pm 0.03$ \\
In sand & 7 & \\
$\quad$ Capsules & 31 & $5.39 \pm 0.36$ \\
Cell + enzyme & 15 & $3.97 \pm 0.19$ \\
PAC + cell + enzyme & 15 & $3.65 \pm 0.65$ \\
\hline
\end{tabular}

The effective degradation time is defined as the period of ${ }^{14} \mathrm{CO}_{2}$ release until the trapped ${ }^{14} \mathrm{CO}_{2}$ is less than $40 \mathrm{dpm} /$ day.

${ }^{b}$ Data for PCP mineralization are the average of duplicate samples. Amount of PCP added in each sample was $1.2 \mu \mathrm{mol}$.

' PAC (5 mg) was immobilized in the capsules, while $10 \mathrm{mg}$ of GAC was used in the Bio-GAC system. Both experimental systems contained $40.5 \mu \mathrm{g}$ of extracellular enzymes and $21.5 \mathrm{mg}$ of cell mass.

d PAC ( $5 \mathrm{mg}$ ) was used in both the capsules and the PAC plus cell mass and enzymes. Extracellular enzymes (37.4 $\mu \mathrm{g})$ and cell mass $(17.9 \mathrm{mg})$ were used for the three systems. 
ments. Also, the PCP (or intermediate) concentration in the aqueous phase for the reference system without PAC was higher than that for coimmobilized capsules and within the noninhibitory range for the degradation. ${ }^{8}$ Under these conditions, the coimmobilized capsules continued the biodegradation for $\mathbf{3 1}$ days, while the reference systems both with and without PAC only had an effective biodegradation period of 15 days. This indicates that hydrogeological and other site properties have less effect on biodegradation by the coimmobilized cell mass and enzymes compared to organisms exposed to the similar environmental conditions.

\section{CONCLUSIONS}

The concept of using coimmobilization for biodegradation at the contaminated environment has been introduced in this study. The primary role of the adsorbent is to remove toxic compounds from the contaminated media and retain them for further biodegradation. The coimmobilization matrix forms a permeable barrier enveloping the cell mass, enzymes, and adsorbent particles. This combination of an adsorbent and an immobilization matrix is expected to create a controllable microenvironmental condition for the biodegradation of toxic compounds.

With suitable design, the coimmobilization process does not reduce the adsorptive capacity of adsorbents. The coimmobilized system could mineralize PCP more effectively than the nonimmobilized system and immobilized system using similar amounts of cell mass, enzymes, and activated carbon. It has also been demonstrated that the coimmobilized system can retain solid cosubstrates to support biodegradation and reduces interference from interrupting microflora. Tests in simulated contaminated soil extract and sand show that coimmobilized capsules have higher degradative ability and stability than the nonimmobilized systems.

This study employed a model system to examine the concept of using coimmobilization for biodegradation of toxic compounds. Further investigations on this concept, the operating mechanism of the coimmobilized system and the design criteria for optimizing adsorbents, immobilization matrices and degrading agents, from the perspectives of utility and economics, are underway.

This research is partially supported by the Environmental Protection Agency, Grant No. R-816155-01-0. Jian-Er Lin acknowledges the Michigan Biotechnology Institute for financial support through UM-MBI traineeship.

\section{References}

1. Bumpus, J. A., Tien, M., Wright, D., Aust, S. D. 1985. Science 6: 1434 .

2. Dawson, G.W., Mercer, B.W. 1986. Hazardous waste management. Wiley, New York.

3. Ehrhardt, H. M., Rehm, H. J. 1985. Appl. Microbiol. Biotechnol. 21: 32.

4. Goldstein, R.M., Mallory, L. M., Alexander, M. 1985. Appl. Environ. Microbiol. 50: 933.

5. Kirk, T. K., Connors, W. J., Bleam, R. D., Hackett, W. F., Zeikus, J. G. 1975. Proc. Nat. Acad. Sci. USA 72: 2515.

6. Kobayashi, H., Rittmann, B.E. 1982. Environ. Sci. Technol. 16: $170 \mathrm{~A}$.

7. Lin, J. E. 1990 Ph.D. Dissertation. University of Michigan.

8. Lin, J. E., Hickey, R. F., Wang, H.Y. 1990. Biotechnol. Bioeng. 35: 1125 .

9. Mikesell, M. D., Boyd, S. A. 1985. J. Environ. Qual. 14: 337.

10. O'Reilly, K.T., Crawford, R. L. 1989. Appl. Environ. Microbiol. 55: 2113.

11. Peyton, T. O. 1984. Enz. Microb. Technol. 6: 146.

12. Reid, I. D., Chao, E. E., Dawson, P. S. S. 1985. Can. J. Microbiol. 31: 88.

13. Siegbahn, N., Mosbach, K., Welch, G. R. 1985. In: G. R. Welch (ed.), Organized multienzyme system. Academic Press, New York.

14. Sigurdson, S. P., Robinson, C.W. 1978. Can. J. Chem. Eng. 56: 330.

15. Sutton, P. M. 1987. Pollut. Eng. July, p. 86.

16. Tanaka, H., Matsumura, M., Veliky, I. A. 1984. Biotechnol. Bioeng. 26: 53.

17. Thomas, J. M., Ward, C. H. 1989. Environ. Sci. Technol. 23: 760 .

18. Ying, W.-C., Weber, W. J., Jr. 1979. J. WPCF 51: 2661. 